\title{
The impact of falling oil price on China's economy
}

\section{Zhao Zhang}

North China Electric Power University, No.2, Beinong Road, Zhuxinzhuang, Changping District, B eijing 102206, China

Email:530891104@qq.com

Keywords: Oil; Decline; Impact; Economy; Deflation

\begin{abstract}
Since the second half of 2014 ,due to the increasing supply of crude oil and the reduced demand resulted from global economic recession, coupled with a stronger dollar, international oil prices continued to fall, decreased more than $60 \%$. New York oil futures hovered nearly $\$ 40$. For China, China's economy is not out of the terrible recession, the decline of oil prices leads to more serious deflation, the economic situation is not optimistic. Therefore, the implementation of monetary policy is increasingly urgent. By drawing on the experience of historical events, combined with the country's current economic situation, this article analyzes the impact of oil prices on a wide range of China's economy, which helps to form an objective understanding.
\end{abstract}

\section{Reducing industrial energy costs and promoting stabilizing growth of industrial}

China is the world's manufacturing powerhouse, and also the oil-consuming nation. According to BP's estimates, China's oil consumption in 2013 accounted for 12.1 percent of total global consumption. So, whether the decline in crude oil prices can reduce the cost of industrial energy sector, resulting in the expansion of production scale, while enhancing the competitiveness of manufacturing sector in the domestic and international market?

Experience from Britain and the US suggests that even if the fluctuant impact of crude oil price in on the economy is asymmetry, but because of the crude oil supply expansion causing the prices decrease, reducing industry costs and improving industrial production.

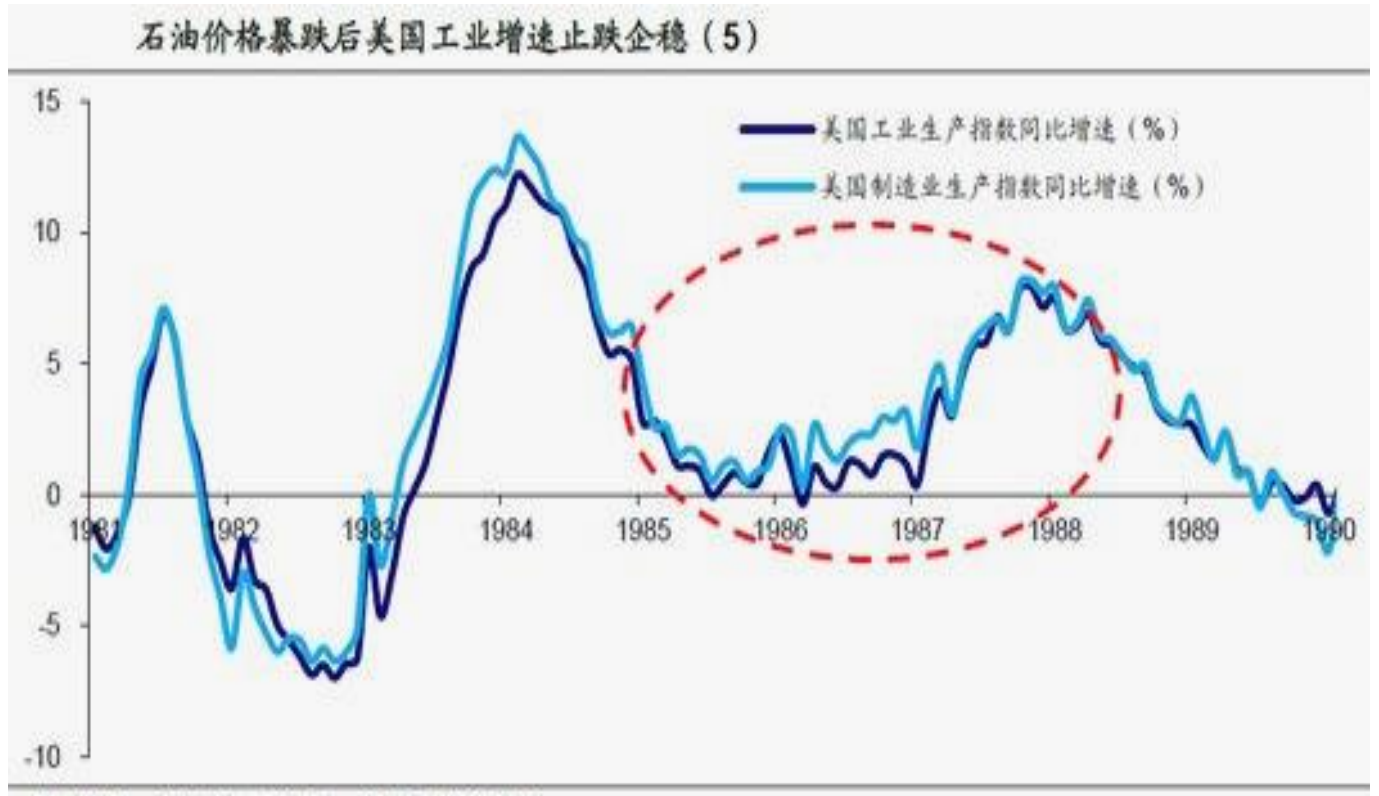

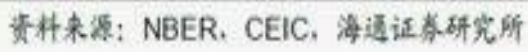

After the second oil crisis, with the production growth of OPEC crude oil , international oil market forming gradually. During the same period, due to the advances in technology, oil exploration and 
development, oil costs continue to decline and production continues to increase, resulting in oil prices plummeting. Between November 1985 to July 1986, Brent crude oil FOB from \$29.8 / barrel fell to \$ 9.6 / barrel, WTI crude oil FOB from \$ 30.8 / barrel fell to \$ 11.6 / barrel. And with oil prices plummeted, the cost of industrial energy in Britain and other major industrial countries (as well as a net oil-consuming countries) dropped greatly.

\section{Enhancing the residents' disposable income, expanding space of government fiscal policy.}

Since 2000, China's crude oil consumption increased sharply. The net imports of crude oil in 2009 exceeded crude oil production, which means more than half consumption of crude oil comes from imports. In 2013, China's annual net imports of crude oil are 280 million tons, approximately 17.6 million barrels. This means that the international crude oil prices fell every $\$ 10,107$ billion yuan will be saved for Chinese enterprises and residents, which is about the equivalent of 0.2 percent of GDP in 2013. Thus falling of crude oil prices will be able to significantly improve the residents' disposable income and boost consumption.

On the other hand, low oil prices will also help improving government revenue. International oil prices fell sharply in 1986, making Britain and other developed countries reduce tens of billions dollars in oil imports. It is equivalent to these countries getting an additional income, which can be used to improve the financial situation. There are two ways to improve the financial situation from oil prices decreasing, one is to reduce inflation and directly reduce the deficit, another is to reduce the deficit by raising indirect economic growth. According to NBER estimates, in the 1980s, the inflation rate in the US decreased every $1 \%$, the budget deficit can be reduced by $\$ 5$ billion. While the US economy increase every $1 \%$, the budget deficit can be reduced by $80-100$ billion.

Comparing the current financial situation in China, the rate of budget deficits raised in 11 years. According to the NDRC predicts, the deficit will reach 2.1 percent rate in 2014. The continuous slowdown of economic growth means that the future expenditure will continue to increase. Deficit ratio is expected to rise 2.5 percent in 2015. Low oil prices are expected to improve the financial situation, and ease pressure on the deficit.

\section{The decrease of crude oil prices exacerbates deflation}

Oil prices decreasing triggered widespread fears of deflation, and the global spread low inflation trend keeps deteriorating. Inspecting several major developing countries, China's inflation rate can be found in the lowest position.

The recent fall in oil prices makes the domestic industries' situation worse. China's current inflation environment is similar to 1998. On the one hand, the inflection point of real estate has shown, on the other hand, excess manufacturing capacity continuing. Specifically, the level of inflation continued to run low, PPI has been in negative territory for 33 months.

This year oil prices goes down incessantly, and refining oil prices decline together. Domestic gasoline and diesel retail prices have generally come down to "6 yuan era", the continuing falling oil prices drive transportation and communication prices fall, but also restricts non-food price inflation.

However, the core CPI fell to1.3\% in November, reaching the lowest since the data record is released, has been out of the stable range. Showing that oil price decrease worsen the deflation situation, but not an important reason leading to deflation, sluggish domestic demand is the culprit.

Although the international financial market is in turmoil, the primary task of the central bank is facing anti-deflation. The deflation leads to the rise of real interest rates, debt ratio deteriorating and makes the economic decline more seriously. The deflation has become the most severe risk. In the long term, the space of easing monetary policy is still large.

Recently there has been a significant devaluation of RMB. Many people worry that China will be forced to raise interest rates like Russia and India. In my view, the devaluation of Russian ruble and 
Indian rupee are not comparable with us. Russia's foreign exchange reserve is mainly dependent on oil dollars, while India's foreign exchange reserves mainly dependent on capital inflows. In the face of falling oil prices and the up valuation of dollar, they are very fragile. The foundation of China's foreign exchange reserves is huge trade surplus, currently maintaining at around $\$ 50$ billion a month. Combined with huge foreign exchange reserves, they have built a huge safety cushion to decrease the impact of the outflow of hot money. Coupled with the current exchange rate remains under control, behind the changes in exchange rates mainly reflects the intent of regulators.

For the current domestic liquidity, the tightness of short-term money is due to the stock market booming. The central bank put money through the traditional open market, the reserve ratio and other tools, so I guess the central bank detour foreign exchange market to launch RMB result in the exchange rate of RMB short-term devaluation. The benefit of this behavior is that both provide liquidity to the market, and prevent the stimulation of the financial bubble.

\section{Conclusion}

This year the central bank continue to ease monetary and M2 continued low growth, indicating that the transmission of central bank monetary policy is blocked. In the past, relaxing made the deposit flows directly to loan funds and reduce financing costs, to stabilize the real economy. Now the funds flow to the financial capital markets, not directly into the real economy. The real economy has not benefited from the short-term.

\section{References}

[1]Xinhua Finance, international oil prices continued to decline [EB / OL], Xinhua, 2008-12-30

[2]Zhao Nong fluctuation analysis [2], the price of oil [J], International Petroleum Economics, 2007, [3]Zhihao Tan Fang Wei, world oil prices and its impact on China's economy

[4]Low oil prices pushed three carriages

[5]Wang Shumin On the impact of fluctuations in international oil prices to China [J]. History Expo (theory), 2009

[6]Oil price data http://www.cngold.org/crude/sanxi.html

[7]Jiang learn Di energy price shocks affect [D] on China's macroeconomic Nanjing University, 2011.

[8]Zhou Zuojie international oil price fluctuations study [D] is associated with the mechanism of economic growth in China. Jiangsu University, 2010.

[9]Wuzhen Xin, Xue Bing, Shuping Wang of China's economic impact analysis [J] VAR model based on oil price volatility of China Management Science, 2011, (01): 21-28.

[10]Lv Dongyue international oil prices: the shock bottoming rebound [J] Chinese petroleum and petrochemical, 2010, (16): 42-44. 